\title{
Considering the Effective Factors on Land use Changes in the Villages Around Metropolises (Case study: City of Rasht, Khomam rural)
}

\author{
REZA SAMIMI SHARAMI*, SEYYED RAHIM MOSHIRI, \\ MASOUD MAHDAVI and PARVIZ KARDAVANI
}

\begin{abstract}
Department of Geography, Faculty of Humanities and Social Sciences, Science and Research Branch, Islamic Azad University, Tehran, Iran.
\end{abstract}

http://dx.doi.org/10.12944/CWE.9.2.34

(Received: July 06, 2014; Accepted: August 09, 2014)

\begin{abstract}
Land use in villages around metropolises, especially in fertile areas such as Guilan plain, is experiencing basic changes. Mutual dependence between the metropolis and its surrounding villages will change rural perspective to urban one and it leads to change rural functions and structures. This review is in the area of Rasht metropolis and about Khomam rural land use changes during 19662013. In this study, research method is descriptive analytical, the data in use is observed through documents and evidences (the oldest and newest map of Khomam rural), and questionnaires and interviews are collected. Research results indicate a significant change in agricultural and horticultural lands and an increase in constructed lands and roadways. This research has tested different indices in order to considering and determining effective factors on land use change. According to research founding, 21 factors have the most effects on agricultural and horticultural land use respectively and 4 factors have the most effects on land use in order to staying unchanged, respectively.
\end{abstract}

Key words: Land Use Changes, Effective Factors, Metropolises Outskirt Lands, Rasht Metropolis, Khomam Rural.

\section{INTRODUCTION}

The pattern of land use leading in villages has being provided by various guidelines and within their framework of physical development. But it has been affected by the mutual relations (metropolis and village) in villages around metropolises, and the development pattern of land use of such villages will be influenced by metropolises. Therefore, the expansion of city of Rasht, as well as many metropolises, has being made to create full domain changes in different fields of surrounding visages life based on demands and needs of urban community.

The rapid rate of urban development of Rasht metropolis and the focus of a variety of services in the area has caused vast changes in the pattern of land use of its surrounding villages. This will be carried out faster especially about the villages which have a central role and are affective.For example, in Khomam rural (one of the villages around Rasht metropolis) from 1966 to 2013, the way and the kind of lands exploitation has been changed. In the past due to the lack of proper networks, people of the village were inevitably self-sufficient for their livelihood and supplying the necessaries. Thus, the agriculture and animal husbandry were considered as the main jobs of rural people, so that many parts of the village lands were under cultivation of rice. But gradually and due to many reasons including immigration and the establishment of appropriate communication networks, the family agricultural system has been dissolved in the villages of 
Khomam and has gradually changed the perspective of Khomam rural areas and caused broad changesin the structures and functions of this village.

This researchassessed various measures to determine and investigate the effective physical, socio economic and cultural-political factors in the change of land use in the village. The present study seeks to answer this question that, firstly, what changes have been occurred in land use in Khomam rural during 1966-2013 and what are the factors affecting the changes(Hall and Pfeiffer 2013)

\section{MATERIALS AND METHODS}

\section{Theoretical Basics}

The rapid rate of urban development has caused wide changes in the pattern of land use of the cities surrounding villages (Hall and Pfeiffer 2013).

Since the best developing agricultural lands were covered by urban development, buildings and urban equipment, in the developed countries of Europe and North America, the best and most urban motherlands have been allocated to the agricultural sector and the most of lands were supported in the state plans titled as theuse plan of national lands. So that in 2000 in the United States, nearly 4 percent of the lands were supported by urbanization and the development of urbanization and urbanism did not lead to the destruction of agricultural lands. In other developed countries, almost $64 \%$ of lands have been also allocated to the agricultural sector and only $6 \%$ has been dedicated to the urban sector.

In these countries, after a period in 1930 s when a part of agricultural lands was occupied by the suburbs (Shakoubi, 1994), factors such as the rise in revenues derived from agriculture, the reduction of birth rate, the implementation of environmental laws and the formulation of regional planning, limited the use of agricultural lands in the urbanization and urbanism. In the years after the Second World War, most of the developed countries created systems of spatial planning. England and the United States were thepioneers in the field of passing necessary laws to organizing the urban lands with an emphasis on the Government involvementto supply the public sector needs to the lands (Housing Foundation of
Islamic Revolution, 2008).In England since far the spatial planning programs has been existed in order to protect agricultural lands from urban development and urbanization and to create a balance betweenregions and territoriestopreservenaturalperspectivesand views. Today, the country's planning system, despite the pressures of economic and social changes, also puts an emphasis on the balance between the natural and built environments. In the United States the spatial planning is also going slowly because there is lots of prejudice and bias about the lack of government involvement in personal and privacy rights, therefore the vast rural areas have made balanced a conflict between cities and rural environments balanced.In the states of this country, the agricultural areas usually have properties such as stopping the increase of the urbanization, the increase of expensive public services, preventing the destruction of natural sensitive perspectives and protecting the open spaces (Simmons, Walker et al. 2010). In a study titled "human motive forces in land use change" in Kunshan of China, the use changes between 1987 to 1994 and 1994 to 2000, using satellite imagery and economic and social information, was investigated. Researchers noted that industrialization, urbanization, population growth and economic development of China are the four human motive forces that have caused the land use changes in Kunshan area(Long, Tang et al. 2007).Japan has provided a successful sample of exact spatial planning and determination of a variety of lands use in Asia. Despite the limitations of soil, the country (whether in terms of the extent and topography) and the relatively high population density and the development of the urban and industrial programs, has been able to control and guide the use changes. $\mathrm{A}$ detailed study conducted in the Ookayama University (Japan) on the land use change of Japanbetween 1975-1990, indicates lack of change in the amounts of forests, increase of the level of orchards as well as the increase of cities and roads level and farmlands have only a reduction of 0.9

The study has tested a variety of indices in order to determine and investigate effective physiographic and socio-economic forces in land use change. According to the findings of the research, the following factors have had the most roles in farming land use change. 
1. Competition between agricultural and urban land

2. Increase of the age average is considered as a factor in the reduction of paddy field.

3. Increase of non-agricultural employment opportunities that is increased parallel to the growth of urbanization.

4. Decrease of the agricultural work returns that will cause immigration to the nonagricultural and decrease of agricultural land.

5. The changes amount of full-time or part time farmer families(Hoshino 2001).

In another research in countryside of Ecuador, it has been expressed that demographic changeshave had a significant effect on agricultural land changes (Jokisch 2002).Davao the second largest city of the Philippines has placed wide rural areas in its legal district, while more urban built parts have been extended on a narrow strip of coast with length of $36 \mathrm{kmm}$ and despite it constitutes $3.6 \%$ of the total city area. It has placed $85 \%$ of the population (Hodder 2005) made in a narrow strip of coast length of $36 \mathrm{~km}$ wide and despite being among the total percentage of the area of city, 85 percent of the population will have its place in city (Hodder 2007). In a study titled "the impact of housing and the cover and land use change" in the Amazon forests of Brazil, these changes and the impact of the housing in four areas was reviewed and it was specified that the level of forests has been decreased between 1986 to 1999 that the lowest and highest amount was 533.97 HA (3.4\%) and $13755.69 \mathrm{HA}$, respectively (9.05\%) (Simmons, Walker et al. 2010).In a study titled "human forces affecting landuse changes on the margins in rural areas in cityof Tonekabon" the economic difficulties and non-economic agricultural activities of the habitants were mentioned as the most important factor of land use change (Mohammadi et al, 2012).

\section{Research Methodology}

This was a descriptive and analytical method. To carry out the study, the customary practices of collecting information (including documentary and field) have been used.

The library studies have dealt with investigating the theoretical resources and the studied records of the discussed topic (in Iran and other countries).In the field study, primary and secondary information has been used and the primary information includes observation and interview (of the authorities and the habitant families) and the secondary information based on study axes have used maps-aerial photos-satellite images and administrative statistics. First, in order to obtain the land use levels of Khomam rural, basic maps of the village was prepared in a 47-year period (It includes the basic map related to 1967, and the basic map related to 2013 of Khomam). Then, based on the existing realities on the maps, the land use status was provided and using the map the levels of each use were separately obtained.The statistical populations of the present paper consist of the land parts that are located in the area of Khomam rural. These parts are divided into two groups: a: The land parts that have changed the land use in a 47-year period, b: the land parts that have been without any land use change in a 47-year period. Because of the wide distribution and relatively large size of thestatistical populations, a sampling method was used in collecting the field data that the amount of this sample is 1000 land parts from which the 600 parts have land use change and 400 parts have been without land use change. In the implementation of the desired test (investigating the factors affecting land use changes) some questionnaire were prepared to be able studying land use changes reasons (whether change or no change) from the land owners' opinion. The prepared questionnaires have been completed

Table 1: The percentage of land use change in Japan between 1975 up to1990

\begin{tabular}{lcccccccc}
\hline $\begin{array}{l}\text { Type of Farmlands } \\
\text { land use }\end{array}$ & $\begin{array}{c}\text { Long } \\
\text { mountainous } \\
\text { land }\end{array}$ & Orchards & Forests & Arid $\begin{array}{c}\text { Urban and } \\
\text { built land }\end{array}$ & $\begin{array}{c}\text { Level of roads } \\
\text { and } \\
\text { transportation }\end{array}$ & $\begin{array}{c}\text { Other } \\
\text { uses }\end{array}$ \\
\hline 1975 & 18.3 & 7.3 & 3.6 & 56.3 & 3.2 & 8.2 & 0.4 & 2.8 \\
1990 & 17.4 & 6.8 & 3.8 & 56.3 & 3.3 & 9.2 & 0.5 & 2.7 \\
\hline
\end{tabular}


in the form of interview during the past two years by the author.

(It is remarkable that in the use change or non-use change, the land parts have not merely been an effective factor from the owners' opinion, but a set of factors have played role. In fact, in studying the factors affecting, each of the options has been calculated of $100 \%$ of the interviewees.)

\section{The Study Area Representation}

The study area is Khomam rural that is located in the North of Rasht metropolis in a distance of $5 \mathrm{~km}$. Abutting Rasht metropolis and being established in a plain bed, being contiguous with pond and beach of Caspian Lake, appropriate climatic conditions, abundant rainfall, high relative humidity and abundance of surface and underground water resources have created competitive advantages for this settlement, since 1966 up to now it has experienced wide changes, particularly in the field of land use changes. Due to the tight connectionwith city of Rasht as the province center capital and very low distance with it, the settlement has always supplied its public services and the needs of city and one of the reasons is the easy access to city of Rasht. Khomam rural despite sending the immigrant has being always faced demographic positive developments and immigration. The economic activities in the village include agriculture, industry and services which have always been reduced in number in agricultural sector by passing the time and added to two other parts especially the services. Traditionally, the agricultural products of the village including rice are distributed all over Iran including Rasht monopolies and Tehran, etc.

\section{DISCUSSION}

The process of demographic developments and land use in Khomam rural Parallel to the drastic increase of Rasht metropolis population (Table 1) Khomam rural has faced the increase of population despite the external migration. (Table 2) Such changes in the context of the residing population in Khomam rural are the field of changes in physical and space structure of the village (especially in the use of the lands). For a

Table. 2: The population changes trend in Rasht metropolis during 1966 to 2011

\begin{tabular}{lccc}
\hline $\begin{array}{l}\text { Time } \\
\text { period }\end{array}$ & $\begin{array}{c}\text { The population of the } \\
\text { beginning of the period }\end{array}$ & $\begin{array}{c}\text { The population of } \\
\text { the end of period }\end{array}$ & $\begin{array}{c}\text { The rate of } \\
\text { population increase }\end{array}$ \\
\hline $1976-1966$ & 146346 & 189263 & 42917 \\
$1986-1976$ & 189263 & 290897 & 101634 \\
$1996-1986$ & 290897 & 417748 & 126851 \\
$2006-1996$ & 417748 & 557366 & 139618 \\
$2011-2006$ & 557366 & 639951 & 82585 \\
\hline
\end{tabular}

Table 3: The population changes trend in Rasht metropolis during 1966 to 2011

\begin{tabular}{cccc}
\hline Time period & $\begin{array}{c}\text { The population } \\
\text { of the beginning } \\
\text { of the period }\end{array}$ & $\begin{array}{c}\text { The population } \\
\text { of the } \\
\text { end of period }\end{array}$ & $\begin{array}{c}\text { The rate of } \\
\text { population } \\
\text { increase }\end{array}$ \\
\hline $1976-1966$ & 3067 & 4014 & 947 \\
$1986-1976$ & 4014 & 7814 & 3800 \\
$1996-1986$ & 7814 & 8585 & 771 \\
$2006-1996$ & 8585 & 12909 & 4324 \\
$2011-2006$ & 12909 & 17106 & 4197 \\
\hline
\end{tabular}

Resource: statistical center of Iran, census of 1966 to 2011 
detailed review of the land use changes of Khomam rural between 1966 to 2012, different levels of use and changes percentage in the referred years have been separately presented in Tables 4 and 5 .

According to the Tables 4 and 5 as well as the land use map of Khomam rural in 1966(Fig. 1-Map no. 1), agricultural use has allocated the most area and orchard use, built (including residential, administrative and commercial) roads and the others have allocated the least area to them. While in 2013 (Fig. 2- Map no. 2). The use area of agricultural land and orchards has been significantly reduced and its area has been decreased to 179 acres. The built use has included the most area so that it has reached from 29 acres to 181. The developments resultant shows that along with increasing the level of built land and roads, the levelof orchards and agricultural lands has been substantially reduced. The continuation of this trend could be very alarming (Center 2008).

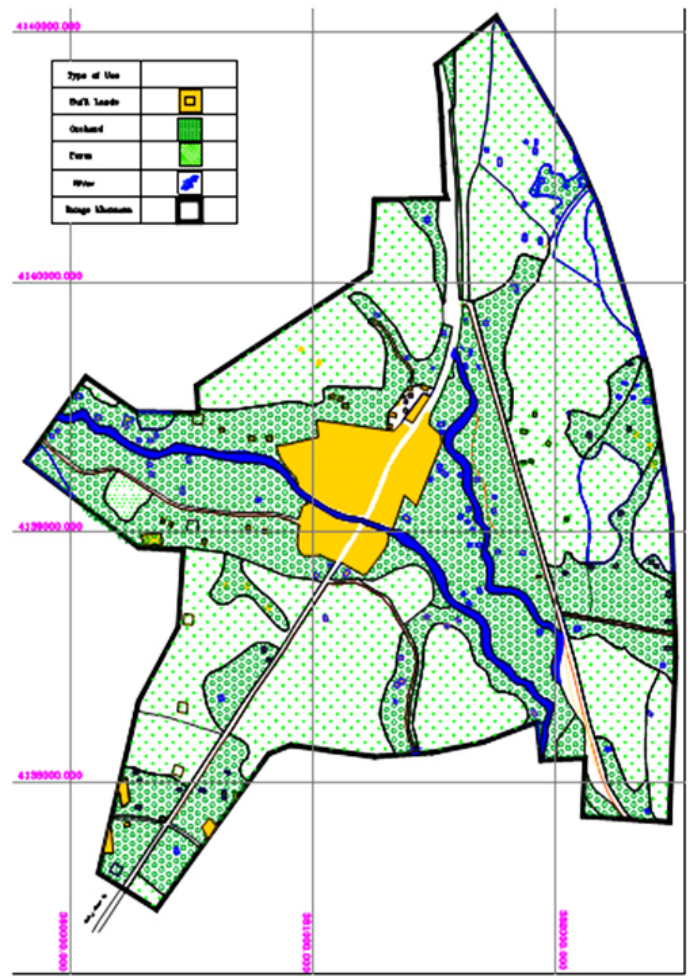

Fig. 1: Map no.1: Land use of Khomam in year 1966
Determining and investigating the effective factors on the change and lack of change of land use More, this research has tested a variety of indices in order to determine and investigate the effective physical, socio-economic and cultural-political factors on land use change of the village. Based on the findings of the study, the following factors have respectively had the most important role in land use change:

\section{The proximity to Rasht metropolis}

Based on the findings of the study, $94 \%$ of the interviewees have known the proximity of Rasht metropolis and access to many public and services needs as the most significant cause of the rural land use change. In fact,from the people's perspective this positional advantage has caused people to tend living in the village and the consequence of such residence is of the effective factors on land use change.

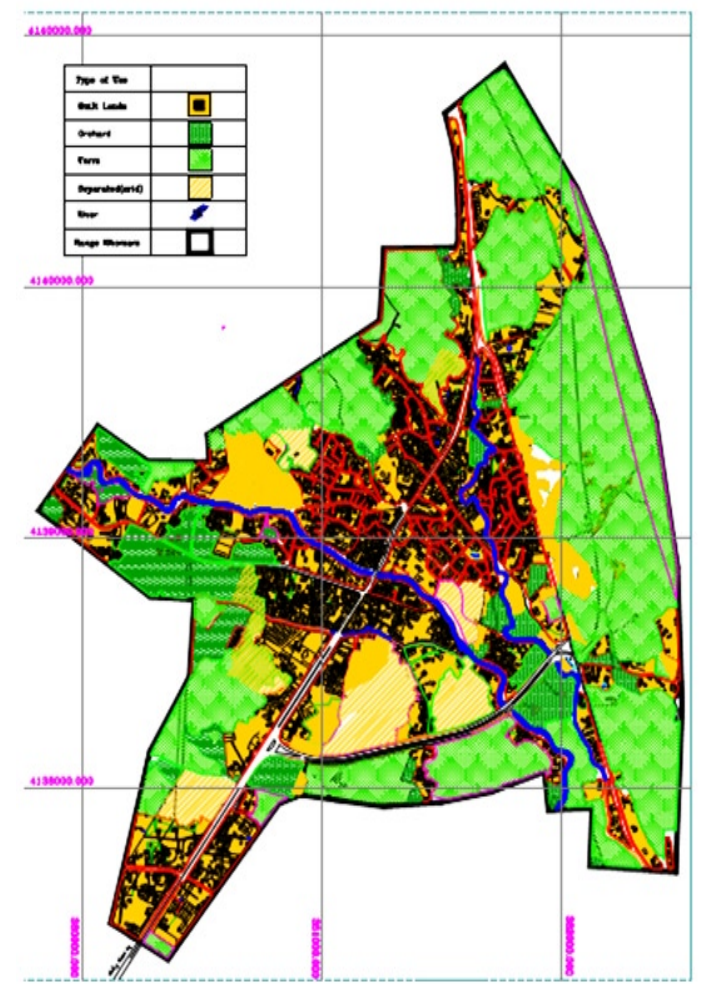

Fig.2: MaP no.2: Land use of Khomam in year 2013 
Reduction of the agricultural work efficiency

Based on the findings of the study, $83 \%$ of

the interviewees that have changed the use of their lands have stated the reduction of agricultural work efficiency and non-economical agriculture as the reason.

\section{Lifestyle change}

Based on the findings of the study, $82 \%$ of the interviewees know the urbanism, the predominance of urban culture, consumerism, and production, work and such these factors' spaces removal as the effective factors on the change of type of life and of course the way of using the land, and form their perspective all these factors have caused the land use change. The research findings show that $78 \%$ of the interviewees have known the average land value rise as one of the important causes in land use change. This issue has caused their major investments to be on land and their perspective to be as a family investment. They know the rise indebted to the appropriate climate position of Khomam, proximity to the metropolis of Rasht and immigration.

Increasing the average age of land owners and no willingness of the new generation to agriculture

Based on the results of the study, $70 \%$ of the interviewees have stated the farm and orchard owners' aging of the reasons for the land use change,while the new generation does not desire to work on the farms and orchards.
The lack of Government's support for agriculture

The results of this research indicate that $68 \%$ of the interviewees know the lack of Government's support of agriculture of the reasons of land use change and from the people's perspective it's of the most important items of their unwillingness to the agriculture. The items such as the import of foreign rice, high cost of planting operation, planting and harvesting, low cost of guaranteed purchase and products sale difficulties have been considered of the difficulties.

The changes of the member of households (especially the farmer households)

The research findings show that $67.5 / \%$ of the interviewees believed that the reduction of households' members of the change reasons, they have suggested that in addition to the lands owners' ageing, the number of households' members have been gradually decreased that this is considered as the reasons of change.

\section{Demographic developments}

Based on the results of the research, $65.3 \%$ of the interviewees have known factors such as birth (increase in population), migration and etc. of the factors of the change and they believe that a part of the changes in land use has been due to the demographic changes.

Table 4: levels of use land of Khomam rural between 1966up to 2013

\begin{tabular}{lcccccc}
\hline Type of use & Built lands & Orchard & Farm & Separated (arid) & Road & Others \\
\hline 1966 & 291514 & 1880658 & 2370895 & - & 200660 & 118578 \\
2013 & 1814067 & 441133 & 1790896 & 278762 & 480671 & 56776 \\
\hline
\end{tabular}

Source: author calculations, $2013^{*}$ levels to M2

Table 5: Percentage of use land changes of Khomam rural between 1966 up to 2013

\begin{tabular}{lcccccc}
\hline Type of use & Built lands & Orchard & Farm & Separated (arid) & Road & Others \\
\hline 2.9 & 4.1 & 0 & 48.8 & 38.3 & 5.9 & 1966 \\
1.22 & 9.88 & 5.7 & 36.8 & 9.1 & 37.3 & 2013 \\
\hline
\end{tabular}

Source: author calculations, 2013 


\section{Proper climate conditions}

The research results show that $63.7 \%$ of the interviewees have considered the appropriate status of the village (reason such as abundant rainfall, high humidity, surface water resources abundance, etc.) as the cause of individuals' tendency to remain in the village for a permanent and temporary residence (in the form of second homes) and the residence has caused many of the use changes.

The provision of housing and schooling and marriage expenses

The results of the study show that $60.8 \%$ of the interviewees have stated reasons such as providing housing for the children, paying their marriage and education cost as the reason to change the land use, in fact from their perspective the land is considered as the most important assets that help them in critical conditions of life.

\section{Division of the inheritance and land fragmentation}

Thefindings show that $59.6 \%$ of the interviewees have known the law of inheritance division as the reason of land use changes especially farming and crop lands that this will lead to shrink the land parts. From their perspective the lands below 2 to 3 acres have no economic aspect for farming and gardening.

\section{The economic problems and supplying the necessities of life}

Total of $58.7 \%$ of the interviewees have known supplying the necessities of life as one of the reasons for land use change and expressed that the economic pressure of life has caused it.

Existence of appropriate infra- and superstructure services in the village

Findings showed $56.9 \%$ of the interviewees know the existence of services such as tap water, electricity, gas, appropriate ways of communication, telephone, etc. of the reasons that have caused the absorption of the population particularly of the surrounding villages, Rasht metropolis etc. and this has caused the land use change from their perspective.
The lack of appropriate plan by government for employment

The results of this research show that $56.7 \%$ of the interviewees now the lack of government's plan for employment as the reason of their land use change, especially for their children, this has caused them to looking for achieving maximum capital by selling their gardens and lands (either in general or with shrinking them) to be able solving their children employment difficulties.

\section{The conversion of Khomam rural to town}

Based on the results of the study, $55.5 \%$ of the interviewees know, the decision of the Interior Ministry between 1976-1986 and the conversion of Khomam rural to the town as of the reasons of land use change in this settlement. They believe that the Government action for it as the stock market of land, the increase of land prices, etc. has caused significant changes in the land use type.

The eland conversion to high-profit use and investment on residential and commercial sections in Rasht metropolis

Our findings showed $54.1 \%$ of the interviewees have stated that changing their agriculturalland and garden use and shrinking them they have proceeded to sell them and invest in various residential and commercial sectors (services) in city of Rasht.

\section{Land brokersactivity}

$53.3 \%$ of the interviewees have known theincreasing activity of the people as land brokers and jerry builders (especially of Rasht metropolis and surrounding villages) of the factors affecting land use changes and they believe that this has had greater intensity especially in the last 15 years. They emphasized on the increase of such people and real states.

\section{Type of land use management by administrative departments}

The results showed that $48.6 \%$ of people know the use change of agricultural lands and gardens in non-compliance practices as the influencing factors on the issue and they believe that despite the existence of the law of not changing lands use especially agricultural ones to other uses, this 
would not be observed particularly in settlements areas, and individuals attempt to do it hidden or through bribes.

The high priceof land and buildings in the metropolis of Rasht and high immigration to Khomam rural

The results showed that $43.2 \%$ of the interviewees have proceeded to reside in the village due to the high cost of land and buildings in Rasht and after residing they have changed the land use where they live or work in this village.

\section{Thehostelry role of Khomam rural}

Based on the results of research, $9 / 39 \%$ of the interviewees expressed that their employment in the metropolis of Rasht and the hostelry role of Khomam rural has caused them to proceed changing their land use in order to reside, second job, etc.

\section{The security of investment on land}

Based on the results of the study, $35 \%$ of the interviewees know the added value resulting from the investment on land and assurance of the individuals' investment return as a reason for land use change particularly (agricultural and garden).

The research findings show that the following factors play respectively the most important role in land use lack of change:

\section{The existence of guide plans for Khomam}

Based on the findings of the study, $93 \%$ of the interviewees have known the existence of guide plans (for some reason, such as considering proposed uses in this plan, the right of separation (5 to $25 \%$ ), designed passages in the plan, etc.) and from their perspective it's better their land to remain in the same form than use it as it's not pleasant to them.

\section{No clear land status and not having ownership document}

The research findings show that $88.6 \%$ of the interviewees have known the lack of ownership document as a reason of the use not to change. They have also suggested that the long process of issuing a document of ownership and a 20-year interruption (Since 2003 to 2012) about the issuance of the document has been the cause of their land use lack of change.

\section{Legal obstacles}

The research findings show that $85.2 \%$ of the interviewees have considered the legal obstacles of their lands land ownership for some reason such asconflict and not clear ownership and capture and long process to specify its status, not clear status of agricultural land, etc. of the factors affecting their land use lack of changes.

\section{Maintenance land for sale}

$35 \%$ of the interviewees have stated land maintenance and keeping it ready for sale as the cause of their land use lack of changes to achieve the most economic added value.

\section{CONCLUSIONS}

Settlements act as the space-location system and on this basis, all the systems' adherence is true about them. Hence any changes in any parts of the system components including physical, socialeconomic and cultural political componentsare related to each other and arethe field to change other components (Moshiri and Saeedi, 2010). Thus, changes occurred in all components of this system, including land-use changes- cannot be and should not be merely considered as changes in physical structure of the settlement. But this basic point must be always noted considered that the components of space-location system of settlements are interconnected and the applied transformation has being derived from other components and it will sooner or later also emanated in other aspect and dimensions of other settlement negatively or positively.

The results of the studies of land use changes of Khomam rural from1966 present the fact that these changes have been effective on land-use changes as a set related to each other, and the relation has gradually changed the perspective of Khomam to an urban perspective. Proximity with the metropolis of Rasht and the tight physical, economic, and services relation between the metropolis of Rasht and Khomam rural, the reduction of agricultural work return, a change in life 
style (urbanization), the increase of land prices more than inflation, farming lands owners' aging and new generation tendency to unwillingness to do agricultural work play respectively the most role in land use change and also factors such as the guide plan for Khomam, not clear status of lands and not having the ownership document, the legal obstacles and maintenance the land for sale have respectively the most role in the land use lack of change.

Finally, since in spatial planning, protecting agricultural lands, orchards (especially fruitful), forests and other environmental areas is necessary and according to the climatic situation of the study area it is recommended to consider the following items:

1. Deep identification factors affecting space structure and organization of each of the settlements and their relation with each other.

2. Formulate the optimal pattern of landuse planning consideration all the legal, economic, social, cultural, and political (ideology), environmental (natural and artificial) factors.

3. Provide terms and conditions of the exploitation of the land in order to avoid indiscriminate increasing of land prices, the stock, etc.

4. Consider the appropriateness of applied developments in usewith cultural and social and economic activities and functions.

5. Pay attention to the limited environmental resources, especially water and soil resources, in rural environments and apply appropriate usewith such restrictions.6. Pay attention to uses conflicts that are more urban and have not much appropriateness with living in rural environments.
7. Pay attention to the future needs of the rural population, especially in the field of the provision of housing and the lack of excesses or wastage in lands allocation in residential units.

8. Balance at the level of the residential uses with the other uses (including services uses).

9. Special attention to the valuable architecture tissue in the uses allocation or change.

10. Attention to the rural identity and face (especially when the socio-economic separations is raised with separation of the village space to traditional and modern parts, in this way in low income strata usually reside in the main cores and old neighbors and around it where the more income groups would settle and therefore the social links will be getting weak).

11. In a comprehensive review, the way of regulating the villages land parts (considering the way of capture and operation) the analysis and the obtained information should be implemented on map (Saeedi, 2008).

\section{ACKNOWLEDGEMENT}

This article is adapted from the rural planning Ph.D. thesis titled as "the physical changesthe space of parts around the centers of provinces during the last four decades in Iran. Case study is Khomam rural-City of Rasht" by Reza Samimi Sharemi under the supervising of Dr. Seyyed Rahim Moshiri and consulting by Dr. Masoud Mahdavi and Dr. Parviz Kardovani in Islamic Azad Usiversity of Science and Research of Tehran.

\section{REFERENCES}

1. Hall, P. and U. Pfeiffer, Urban future 21: a global agenda for twenty-first century cities. 2013: Routledge.

2. Simmons, C., et al., Doing it for themselves: Direct action land reform in the Brazilian Amazon. World Development, 38(3): 429-444 (2010).

3. Long, $\mathrm{H}$., et al., Socio-economic driving forces of land-use change in Kunshan, the Yangtze River Delta economic area of China. Journal of Environmental Management, 83(3): 351-
364 (2007).

4. Hoshino, S., Multilevel modeling on farmland distribution in Japan. Land Use Policy, 18(1): 75-90 (2001).

5. Jokisch, B.D., Migration and agricultural change: The case of smallholder agriculture in highland Ecuador. Human Ecology, 30(4): 523-550 (2002).

6. Hodder, R., The Philippine legislature and social relationships: Toward the formalization of the polity? Philippine studies, 63-598 
(2005).

7. Hodder, R., Philippine Studies vol. 55, no. 1 (2007): 88-115 Copyright@ Ateneo de Manila University. Philippine Studies, 55(1): 88-115 (2007).

8. Center, I.S., Report of the 2006 census of housing and population of Iran. Tehran, Iran: Iran Statistical Center, (2008).

9. Center, I.S., Report of the 1966 census of housing and population of Iran. Tehran, Iran: Iran Statistical Center, (1968).

10. Center, I.S., Report of the 1976 census of housing and population of Iran. Tehran, Iran: Iran Statistical Center, (1978).

11. Center, I.S., Report of the 1986 census of housing and population of Iran. Tehran, Iran: Iran Statistical Center, (1988).

12. Center, I.S., Report of the 1996 census of housing and population of Iran. Tehran, Iran: Iran Statistical Center, (1998).

13. Center, I.S., Report of the 2011 census of housing and population of Iran. Tehran, Iran: Iran Statistical Center, (2013).

14. The Islamic revolution Housing Foundation,
"Rural land use studies Guide", The Sharif publishing Co., 1: 172 (2008).

15. Saeedi, Abbas, "The basics of rural geography”, Samt publisher., 1: 189-191 (2009).

16. Shakoubi, H., new perspectives in urban geography", Samt publisher, 1: 166 (1994).

17. Sasba, Tavana, M., Amir Entekhabi, Sh., , "The process of converting the village to the town and its implications in city of Talesh", geography and development, 10: 107-128 (2007).

18. Mohammadi, M., "effective human powers on land use changes on the silelines of rural areas in city of Tonekabon, geography, 35 : 279-298 (2012).

19. Moshiri, M., Saeedi, A., "Rural land use patterns and methods of preparation", The Islamic revolution Housing Foundation publisher, 1: 411 (2010).

20. The basic map 1966, Khomam, mapping organization.

21. The basic map 2013, Khomam, mapping organization.14. 